\title{
Measures of small business success/performance - importance, reliability and usability
}

\author{
Article history: \\ Received: 26 November 2014 \\ Sent for revision: 15 December 2014 \\ Received in revised form: 20 April 2015 \\ Accepted: 5 May 2015 \\ Available online: 2 July 2015
}

\begin{abstract}
The main objective of this paper is to assess the reliability of selected measures of success/performance of small enterprises taking into account all the advantages and disadvantages of objective (traditional, financial) and subjective (personal perception) indicators. The realization of the basic objective will enable removal of doubt in different categories of success / performance of small businesses, which would be a secondary objective of the paper. The research methodology involves the use parametric procedures due to the characteristics of the selected variables and the number of observations in the sample. Univariate ANOVA and Pearson's coefficient correlation will be the main methods used. The basis of this study consists of data gathered from e-survey of 260 entrepreneurs/ owners/ managers of small enterprises in administrative sub-region of the Republic of Serbia. The analysis results show the correlation between subjective estimate of success of owners/ entrepreneurs/ managers and objective performance indicators, which can be characterized as complementary, meaning that subjective assessment as well as formally stated performance indicators are realistic. In addition, it is important to emphasize as an important result within the group of objective performance indicators, the differences between two groups, financial and non-financial, performance indicators.
\end{abstract}

Keywords: measures, success/performance, small business

\footnotetext{
${ }^{1}$ University of Novi Sad, The Faculty of Economics Subotica,

${ }^{2}$ University of Novi Sad, The Faculty of Economics Subotica, marics@ef.uns.ac.rs
} 
Leković B., Marić S.: Measures of small business success/performance - importance...

\section{Mere uspeha/učinka malih preduzeća - značaj, pouzdanost i upotrebljivost}

Apstrakt: Osnovni cilj ovog rada je da se proceni pouzdanost odabranih mera uspeha/učinka malih preduzeća, uzimajući u obzir sve prednosti i nedostatke objektivnih (tradicionalnih, finansijske) $i$ subjektivnih (lična percepcija) indikatora. Realizacija osnovnog cilja će doprineti uklanjanju sumnje u različite kategorije uspeha/učinka malih preduzeća, što će predstavljati sekundarni cilj ovog rada. Metodologija istraživanja podrazumeva korišćenje parametarske procedure zbog karakteristika odabranih varijabli i broja opservacija u uzorku. Univariate ANOVA i Pearsonov koeficijent korelacije će biti osnovne metode ovog rada. Osnova ovog rada sastoji se od podataka prikupljenih iz elektronskog upitnika 260 preduzetnika/vlasnika/menadžera malog biznisa $u$ pod regionu Republike Srbije. Rezultati analize u ovom radu ukazuju na vezu subjektivnih procena uspešnosti vlasnika/preduzetnika/menadžera i pokazatelja objektivnog učinka, koji se mogu okarakterisati kao komplementarni, što znači da je subjektivna procena, kao i navedeni formalni pokazatelji poslovanja predstavljaju realno stanje. Pored toga, važno je istaći, kao važan rezultat koji se primećuje u okviru grupe objektivnih indikatora učinka a to je postojanje razlike $i$ razgraničavanje dve grupe, finansijskih $i$ nefinansijskih, indikatora učinka.

Ključne reči: mere, uspeh/učinak, mala preduzeća

\section{Introduction}

Assessing the category of performance and success of small business represents one of the key points of this paper. There is no strong determination what the previously mentioned categories mean, as there is a wide range of variables for accessing performance/success. Most management practices are based on the methods and procedures developed for large companies where financial and operative goals are precise and clear, and can be easily translated into concrete actions (Simpson, Padmore, \& Frecknall-Hughes, 2007). As for small businesses and the correlation between management practice and success/performance, i.e. possibilities of advancement (Rue \& Ibrahim, 1998; Perry, 2001; Gibson \& Cassar, 2005; Simpson et al., 2007), there are some issues relating mostly to objective assessment. According to some authors, success is interpreted as a specific performance aspect (Brush \& Vanderwerf, 1992). Other authors interpret success as high performance (Brooksbank, Kirby, Tompson \& Taylor, 2003), while some authors relate success to growth or profitability (Perren, 2000). Due to different concepts of success and performance, as well as the 
measuring method, there is a need for their precise limitation and definition. As for owners/ entrepreneurs/ managers (OEM) of small businesses and a wide range of their goals as quality independence and life styles (Jennings \& Beaver, 1997), it speaks enough about the complexity of problems. Expressing success by means of financial indicators, as the total income per employee, profit per employee or the period to return investment, is not enough in the context of small businesses, regardless of the fact they are easily measurable as they disregard alternative success criteria based on personal goals of owners/ entrepreneurs/ managers. Personal goals of owners/ entrepreneurs/ managers often do not have to be harmonized with business goals, and financial indicators do not often report on them, which additionally complicates the current situation. Some financial categories, such as overall income, profit, property, since quantitative statements are differently calculated, relativize the category of financial indicators and their value, i.e. their usefulness to assess performance. When it comes to success of small businesses, i.e. owners/ entrepreneurs/ managers, it is the subjective, absolute category as a measure in realizing the goals of the enterprise, which can be simple and unique and thus reflect aspirations and motives. Performance represents the objective dimension of success as a multidimensional, qualitative and quantitative expression of success compared with other enterprises or relevant groups of enterprises. Such defined and limited categories of success and performance show that an enterprise can be successful in reaching set goals and achieve unsatisfactory, good, high, optimal level of performance regarding growth and development as a multidimensional expression of success (Jennings \& Beaver, 1997).

As for the analysis focused on the group of small businesses, as a pattern and basic set defined in this research, the principal resource for comparison according to the dimension of relative success is, of course, the performance expressed to selected indicators that represent, in an ambiguous way, this category. The selection of indicators for reporting performance level is the key factor of success of all attempts by this and similar research, which have performance as an independent variable. Lumpkin and Dess are very precise in researching multidimensional performance nature, determining it for traditional indicators of growth, market participation profitability, satisfaction of stakeholders, etc. (Lumpkin and Dess, 1996). In this research, all indicators of growth, development, profitability are selected in order to measure performance of small businesses. The previous selection represents one consensus on the theme of indicators and it is pointed to the research carried out by Murphy et al. within 51 works, where he identified 71 different measures of performance and classified them in nine main groups, where growth and profitability had the biggest frequency (Murphy, Trailer \& Hill, 1996). On the basis before statements and defined research area the central research aim and key problem orientation as a basic intention of this work is 
Leković B., Marić S.: Measures of small business success/performance - importance...

to answer the question on how we can measuring success/performance of small business and identification of importance, reliability and usability different types of measures.

In the paper there is a set following objectives:

- To identify differences between two type of measures of small business success/performance;

- To identify reliability usability of objective and subjective measures of small business success/performance.

The rest of the work is outlined in four parts. The second part points to the theoretical background of the research problem. The third part illustrates the methodology and sources of data processed by statistical procedures. In addition, in this part, selected indicators as research variables are specially represented. The fourth part comments the results carried out by statistical analysis, while the fifth part is reserved for conclusions.

\section{Success/performance of Small Business - Theoretical Background}

Two significant management dimensions in the domain of success measuring of business systems are effectiveness and efficiency. Effectiveness dimension is oriented towards the choice of the right goals (doing the right things) which will have the market verification by consumers while efficiency dimension is determined by the degree of rational use and engagement of available resources (doing things in the right way). It is possible to be successful only with effectiveness but for a short time, while the complete success is guaranteed when both dimensions are realized at the high level. The analyses of some literature in the field of management, business and entrepreneurship with a view of searching for success criteria of owners/entrepreneurs/managers can give numerous terms used for defining the mentioned category. Business performance, entrepreneurial success and owners' success goals can be met.

The category of success/performance is set as a dependent variable primarily in relation to management practice and the volume of management activities in small businesses in order to explain connections and possible influences in the direction of improving business results. Therefore, it becomes necessary to precisely understand and restrict the notions of success and performances that are usually used as synonyms. It is also necessary to define criteria which really measure success of small businesses.

Every business project/business/enterprise originates, exists and aims at something that is generally called success. Starting from the classic economic 
framework and its representatives as J. B. Say (1971), who defines success in entrepreneurship by means of quality as judgment, persistence and the "world knowledge in the field of business, i.e. success precisely, it requires economic knowledge, as well as business experience. In the same way, an entrepreneur can go bankrupt, not exclusively because of his/her mistakes or faults, but part of failure can be explained by bad luck. Alternatively, it depends on general business conditions. Marshall (1890) explains his success by possessing general possibilities (family origin), special possibilities (having appropriate knowledge and skills), capital and good luck. The entrepreneur possessing the previously cited possibilities has significant advantages relating to others. Schumpeter's entrepreneur is innovative and it is the basic precondition for any entrepreneurial project. Enterprises or individuals not inspiring innovations cannot provide survival. According to Knightian (1971), success of entrepreneurs requires the power of effective control and intellectual capacity, as well as self-confidence and orientation of activities based on own opinion. The entrepreneur is expected to be creative and possess the power of anticipation. The previously mentioned capabilities obviously depend on the economic branch, business experience possessed by the entrepreneur and knowledge of consumers' wishes, which largely increases the possibility of success. At the end, a successful entrepreneur should possess superior management capabilities; therefore, belief in good luck is justified. Analysing these attitudes about necessary possibilities and skills for reaching entrepreneurial success, we can notice some complementarities, as well as contradictions of cited authors as management capabilities; leadership, capital, psychological factors, as well as determinants of success that are characterized in different ways and different degree of importance.

The dilemma existing in the title of this paper found its place and role because of specific relationship between owners/entrepreneurs/managers within their own enterprises. Mutual interweaving and connection between the roles of entrepreneurs, owners and managers, their personal and business ambitions largely befog this topic, and thus hamper objective measuring and expressing success/performance of small businesses.

If we start from the general definition of success as a measure in realizing the goal, to accept this dilemma is perhaps unnecessary or there is no reason for it, at the end. If we can answer the question of what the goal is in our case of entrepreneurial projects, i.e. the entrepreneur as an individual and person in charge, then the performance relating to the reached results determines the measure of success.

This field of entrepreneurial and small business has significant shortcomings, disregarding numerous studies and previous research, especially relating to 
Leković B., Marić S.: Measures of small business success/performance - importance...

accepting and realizing some success criteria, which is not sufficiently represented by authors of entrepreneurial studies.

Various research in the field of reporting and measuring success/performance resulting from the application of appropriate practice and procedures, use the classic financial indicators, which are not often comparable because of different calculations and contents of basic financial statements. The field of measuring success is often connected to researching critical factors of success, while definition of business success and performance is set quiet widely and imprecisely, largely due to numerous limitations existing in this topic.

As the basic motivators of individuals for assessing entrepreneurial success are still unknown or restricted and set imprecisely, or they are primarily personal, there is a justified aspiration to contribute to understanding of every way of measuring success of owners/entrepreneurs/managers within every next research. Taking into consideration their personal values, since entrepreneurial personality is largely incorporated into business project by the analysis of many previous as well as current researches, we can notice numerous criteria used by entrepreneurs for success measuring. Success criteria connected to technical aspects of management and finances are partly distinguished, where profit and growth maximization dominate (Wilson, 2004). Available literature points to the fact that owners/entrepreneurs/managers also use other criteria, especially in the domain of personal ambitions in order to evaluate their own success where social influence and personal satisfaction prevail.

\subsection{Measuring success/performance of small business}

The debate regarding the contents of success and way of defining and measuring performance in small business is always open. Success and performance of small business are very narrowly connected, which is confirmed and emphasized by many authors, like Brush and Wanderwerf (1992), Brooksbank et al., (2003), Rogof et al. (2004), Perren, (2000), Curran, Kitching \& Lightfoot (2000), Jarvis et al. (2000) and Jennings and Beaver (1997). Having considered these two categories, we can find explanations that success is a specific aspect of performance or is identified with high performance. Some of them recognize success in growth and profitability, but this aspect has significant shortcomings in the field of small businesses where goals do not coincide, comparison and a real success statement are difficult to be presented. Financial indicators are simple for success definition and statement, but they can ignore the possibilities of alternative criteria for success definition, based mainly on personal goals of owners/entrepreneurs/managers. In addition, contrary to the current conviction and significant part of economic theory, money and indifference of 
financial realization are not significant for engagement of individuals, responsibility and the independence of style and life quality to which owners/entrepreneurs/managers of small enterprises can aspire. All this indicates significant complications and aggravating circumstances in defining and measuring success of small enterprises, mostly because of goals of owners/entrepreneurs/managers. In business, an enterprise can be considered successful if it realizes the optimal level of performance regarding growth and development. However, it is noticeable for small businesses, although rarely, and only in the conditions of strong connection between job and owners, that personal success is identified with business success, while in other cases nonfinancial criteria and the lifestyle are far more significant.

As these suppositions are known, the next task, as well the key topic of this paper is a precise determination of entrepreneurial goals, i.e. if they are more at the personal or business level, as well as if the general determination is possible or individual circumstances and determinations are possible.

It is visible from the previous part of the paper, where the dilemma of success is fully analysed trying to compare and restrict with performance; success definition is not a simple task for any kind of business, especially for an entrepreneurial project or a small enterprise. The definitions of success in this field are very different, often controversial, and they are in the span of survival to the reach of some level of usual financial indicators. The problem of success determination is even more complex in initial stages of small business development, i.e. when the entrepreneurial project is in the nascent phase, in the first months of business. Mostly, it is the period before the first annual balance sheet when the new business projects miss data on previous business for the purpose of comparing their results. As the nascent period of small business is very critical and unstable, it is impossible to expect some noticeable results because of numerous burdens in this development stage in the form of low business result, payment of high interests and high starting costs, which are insufficient to characterize the enterprise as unsuccessful. It is even usual to positively, almost successfully, evaluate this entrepreneurial project in this phase of development if it reaches some market segment or has a good image. Some authors like Man et al. (2002) speak about success regarding the competitive analyses of the first business years in order to evaluate potential development of the enterprise and they are very discouraged when it relates to the use of financial measures.

The small enterprise is not only a simple miniature of large companies. It possesses some characteristics because of significant role of owners/entrepreneurs/managers and their influence on business activities, because it causes conflict relationships between subjective and objective measures of success. As owners/entrepreneurs/managers are present in every business activity of small business, to carry out research at this level 
Leković B., Marić S.: Measures of small business success/performance - importance...

means also to consider attitudes, aspirations and activities of the owner himself. Accordingly, it is necessary to determine how owners/entrepreneurs/managers of small businesses experience success and how their perception of success influences the enterprise performance.

Enterprise performance can be evaluated by the objective (traditional, financial indicators) and subjective (personally oriented) approaches. Enterprise performance is exclusively stated by objective measures of success, while success from the perspective of owners/entrepreneurs/managers can be stated by both financial and nonfinancial measures of success.

Many authors led by specific research results suggest that success should be considered from the subjective perspective so the starting point in the process of evaluation are the owners/entrepreneurs/managers themselves (Stenberg, 2004, Simpson et al. 2004). Traditional financial success measures for owners/entrepreneurs/managers of small businesses can be insignificant, senseless or inappropriate as every individual has his/her own perception of success (Simpson et al., 2004). Therefore, subjective success criteria understand measures as personal satisfaction and accomplishment, business proud or the flexible life style.

Success is the consequence of several factors. Success is primarily determined by the characteristics of owners/entrepreneurs/managers as selfefficiency in finding opportunities, persistency and social skills (Markman and Baron, 2003). The second group of factors includes market possibilities, number of business partners, capital as well as the selected strategy to reach success (Simpson et al. 2004).

One of the ways to define success as a measure in reaching goals is that the choice of goals is the basis for success. Therefore, these goals have three tasks in the enterprise's success to form suppositions of success, direct behaviour in accordance with success and the operative task as a measure of success.

Owners/entrepreneurs/managers differentiate according to set goals, and thus the importance of both economic and noneconomic goals has a different role for every individual. Therefore, goals direct attention and behaviour, and the choice is directly connected to motivation, since the individual defines and sets goals, so naturally he will try to realize them. Motivation to become an entrepreneur is significantly connected to the criteria for success measurement. The basic supposition of entrepreneurial motivation in the form of self-employment is the aspiration to increase personal welfare. Motives influence the choice of some kind of goals, which will be set. Therefore, goals become criteria for success, and owners/entrepreneurs/managers measure their own success by the degree of goals realization. Thus, 
owners/entrepreneurs/managers that are successful in realizing set goals can be considered successful.

Besides usual and most used measures for the performance of profitability and growth (number of employees), some authors use business period as a practical measure of individual business success (Luk, 1996, Sapienza and Grimm, 1997, Bruders et al., 1992, Pennings et al.,1998). In a detailed analysis of success/failure of the small enterprise, business period can be a reliable indicator of success only if a small enterprise is closed down or business project is cancelled non-voluntarily, i.e. if it is a forced collapse. The forced closing down or business collapse happens after some period when it is impossible to continue with business. This form of closure of business is explained as collapse or bankruptcy. On the other hand, business can be a voluntarily closed down (transition from self-employment to employment or unemployment) because of the lack of readiness or motivation. Generally, we can talk about voluntary and forced closure of own business, while survival as a measure of success of small business implies the period of doing business that will be ended by some forms of business closure without a new form of self-employment (to be self-employed in some period). Therefore, the measure of success of small business is determined by business period, which will be ended exclusively by forced and non-voluntary leaving of own business. Consequently, we can conclude that in case of the research on the sample of active small businesses, i.e. by researching the current owners/entrepreneurs/managers we can notice that the small enterprise with longer period of existence is more successful. We can definitely agree that, due to problems of measuring success, especially in the early stages of small business when already familiar conventional measures of success are insignificant and useless, the identification and measuring survival as a measure of success is very easy.

From the analysis of frequency in using some success criteria in the survey of Brinckman et al (2010), the example of 51 works classified in three fields, measures of growth-oriented performance, profitability-oriented performance, and bankruptcy-oriented performance, some performance measures dominate in the form of the growth of sales, profit and bankruptcy. Above mentioned attitudes for the use of performance measures by Murphy et al., (1996), Lumpkin and Dess (1996) and the analysis of Gorgievski, Ascalan \& Stephan (2011) completely justify and confirm a good choice within this paper. It relates to the criteria of growth, profitability and survival as primary success measures.

Most previous research in the field of measuring and reporting performance of small businesses as dependent variables was based on financial indicators and measures. Although they are highly useful for conducting research and analyses, financial indicators show shortcomings in different treatment of 
some categories in financial statements, as well as in different calculation of these indicators. We can conclude that financial indicators may not be the best and most reliable way to measure performance because of some weaknesses which they show. These shortcomings of financial indicators are not typical only to small businesses but they are present with larger business systems (medium and large). Due to undeveloped management systems, as well as the systems for performance measure with small businesses and because of different business motives connected to the entrepreneurial personality, inconsistencies are far bigger, as well as negative consequences. Analysing the biggest shortcomings of financial indicators, an adapted example will be useful, Survey 7 of Hughes, Simpson \& Padmore (2007), where the key problems are cited and explained. The need and the basic reason for adaptation are seen in the change of the term indicator because the problem does not generate the relationship between two categories, as it is just the relation, not the contents, i.e. the structure of categories themselves.

To know all these problems connected to financial indicators is quite enough in order to apply the multidimensional approach in measuring performance as there is no real way to eliminate these problems. Regardless of all shortcomings of financial indicators, their application in performance measuring is necessary because of, first of all, the simplicity of calculation and wide application. However, it is not a simple dimension of performance measuring, but a combination with other aspects of performance in order to reduce the shortages of financial indicators, as well as to recognize more objective business performance of the enterprise. Various studies confirm this, which are still researching the topic of business performance as a dependent variable disregarding the spectrum of research results in this field of many authors (Venkataraman \& Ramanujam, 1986; Murphy et al., 1996).

Satisfaction can also be in accordance with the basic subjective measures of success, which primarily does not mean attaining goals, but is something that brings the sense of success. Satisfaction is partly determined by the gap between personal standards and wishes of owners/entrepreneurs/managers and the current level of realization of the set goals. It means that the full level of satisfaction cannot be realized without the complete realization of set goals. In addition, the enterprise's performance is the consequence of needs, readiness and possibilities. It represents internal and external factors connected with owners/entrepreneurs/managers, enterprises and the environment.

It was usual that the only indicators for measuring success were of the objective nature disregarding all the shortcomings and some aggravating circumstances in their application. Many authors point to the possibility and importance of the use of subjective measure, which can be very efficient and 
real evaluation measures of success, but the best way to provide information that is not possible to collect in any other way. Authors Wang and Ang (2004) established three main reasons why it is better to use subjective than objective success measures:

- First, most small businesses cannot or are not ready to provide objective information on business, especially in the first year;

- Second, accounting data in these enterprises are very complicated for interpretation;

- Third, if the sample is formed by enterprises in different economic branches, then the circumstances of economic branches exert big influence on accounting data.

Subjective success measures are not complete or perhaps perfect, to which justified reviews point because of big participation of subjective components making them inappropriate for comparison between enterprises (Reid and Smith, 2000). The advantage of this group measures is confirmed in comparing data on subjective perception of success of owners/entrepreneurs/managers with objective data of performance. In this way a high positive correlation between these groups of data is identified so high preciseness in expressing success of subjective measures is emphasized (Baron \& Markman, 2000).

To reduce mistakes, as well as potential shortcomings of future results and conclusions because of the nature of entrepreneurial projects and small businesses, we decided to enable owners/entrepreneurs/managers, within this research, to freely report on subjective feeling of success of their own business projects, as well as the degree of taking into consideration their personal and family criteria in measuring business success.

We should emphasize that financial performance measures of small business are not sufficient to express real and objective business results and report on business success because of all previously cited shortcoming. However, as subjective measures cannot be easily measured and compared, the former mentioned choice is rationally necessary, i.e. the combination of subjective and objective success measures is desired.

\section{Methodology}

\subsection{Sample and data}

The field of research, i.e. the basic set of this paper is small business in the Vojvodina Province, the Republic of Serbia. Because of scarcity and feasibility 
of research work, manifested in the volume of sample, the basic set is limited on the geographical area of the Vojvodina Province. The administrative classification of the chambers of commerce in the Republic of Serbia, according to the Law on Accounting and Auditing (Official Gazette of the Republic of Serbia, No. 46/06, 111/09, 99/2011 and 62/2013), recognizes the group - the sector of small and medium enterprises and entrepreneurship. According to available data of the Business Registers Agency, 2603 enterprises are classified into small businesses. The sample used for researching has the characteristics of a proportionally stratified sample. Most sample proportions in relation to the basic set amounts to 0.10, i.e. 260 small businesses and it is satisfactory if we take the number of variables represented in the questionnaire. The research was conducted during 2013. Stratification will be done based on regions in order to adequately represent the basic set from the spatial aspect.

As seen in the previous part of the paper, the subgroup of small businesses appears as the selected area of research, where the category of micro enterprises, consisting of less than ten employees is excluded. The reasons are exclusively of the substantial nature and they significantly exert influence on the quality of research. Such defined basic set, small enterprises without micro enterprises, is completely compatible and comparable with the same segment of chambers of commerce defined in the European Union and in the surrounding countries, but not yet in our country. In analysis of interpretation and usefulness of research results based on realized compatibility of the area of research, the basic set and sample, we get a wider region in the temporal and spatial sense, for dissemination and application of research results. Besides micro enterprises, the post segment of medium enterprises is also excluded because small enterprises have expressive characteristics in relation to medium enterprises in this kind of research. As at initial stage in development and the life cycle of enterprises considered from the aspect of its size, small enterprises have a significant distance in relation to medium ones when it is about management practice and the level of its application, and thus the level of the realized success, as well as the characteristics of expressing business results. Management orientation and the intention for the long-term existence and the realization of own mission make small businesses officially accepted as the subject of economic activities. The existence of management orientation clearly differentiates small business from entrepreneurial projects as Wickham (2004) visually explains it. However, the same initial management practice largely differentiates qualitatively small business from medium enterprises, as the next administrative stage in development, where management is present at one, mostly higher professional level. That is why small enterprises are separated from the segment of medium ones and excluded category of micro enterprises represents a homogeneous entity, i.e. one qualitative, precise and clear 
Leković B., Marić S.: Measures of small business success/performance - importance...

limited research field. The paper has to precisely determine the key research variables in order to interpret causes, relationships and connections of some results with some dose of reliability and usefulness.

\subsection{Questionnaire and research}

Observed variables are features. Features in relation to the sample that is divided on subsample are criterion for success characteristics of success/performance (C2) and C2a - survival, C2b - growth, C2c profitability and $\mathrm{C} 2 \mathrm{~d}$ - development as dependent characteristics in the form of criteria for defining success of small enterprises. Many features, mutually and logically connected, make a logical entity (C) as it is C1 - general characteristics of owners/entrepreneurs/managers and enterprises, C3 management knowledge and formal management practice, and C4 - the environment. They are simply called the "entity" (space). The entire observed thematic entities make the research space. In this paper, data relating to the entity C2 of research space are used.

The basic method used for collecting answers in the questionnaire is the esurvey method where the principle of electronic communication ( $g$-drive) will be used with the respondents (in this case with owners/entrepreneurs/managers in small business selected in the sample), taking into consideration all advantages and shortcomings of this method. Respondents are sampled according to the principle of every tenth in the list formed by the Business Registers Agency of the Government of the Republic of Serbia.

\subsection{Hypotheses and methodology}

Taking into consideration that the research is aimed at clear problem orientation, defined in the previous part of the paper, the following research suppositions in the form of hypotheses are set:

H1: There is a high level of reliability and usability of subjective success measures (in the form of subjective satisfaction about realizing the goals of owners/entrepreneurs/managers) as the positive correlation with objective (financial and nonfinancial) indicators of performance.

H2: There is a high level of reliability and usability of objective success measures (in the form of formal reports) as the positive correlation between two subgroups of objective (financial and nonfinancial) indicators of performance.

Pearson's correlation will be used for researching the connectivity of selected constant variables, previously defined research suppositions. The correlation 
Leković B., Marić S.: Measures of small business success/performance - importance...

analyses and shows the direction (positive or negative) and the strength of connection (the dimension of correlation coefficient ( $r$ ) with the level of significance) between observed variables.

\section{Results of research and discussion}

The connectivity of research appearances in this part of the paper and their role and importance for the success of small business will be tested thanks to the dependent group of selected variables of success/performance. Before testing the hypothesis and interpretation the results of selected statistical methods for testing observed appearances, we will dedicate one part of the research to evaluate selected indicators of success/performance of small enterprises. It means to what degree the subjective evaluation of success of owners/entrepreneurs/managers are complementary to objective, classic and financial indicators of success. This is one of the most delicate research fields in this paper as the official financial statements on that basis generate objective measures of performance and represent a specific field of small enterprises in regard to selected methodology, intentions, trust, openness and readiness. It should represent actually owned business which with small enterprises has the biggest degree of personal aspect in relation to companies of other categories of the dimension.

In accordance with the choice, after the previous research results and citation of the valid and current theoretical attitudes, reliability and credibility of selected subjective and objective performance indicators will be tested by the Pearson coefficient of this correlation. The aim of this analysis is to test the complementariness of these two categories of indicators as they show some features regarding the real statement when they are small enterprises. It is known that this method tests the power and direction of connection of the observed variables as, in this case, the segment of objective indicators are the indicators of profitability and growth contrary to the subjective evaluation of business success of own project.

In the table 1 , the results of correlations between observed variables can be seen. We can see that between variables C2d.01 measure success solely on the achievement of the objectives of the private plan (scale $1-5$, where 1 is false and 5 is true) and variable C2d.02. I can consider successful the business of my own company (at the scale from 1 to 5 , where 1 is incorrect, and 5 is correct) and where there is the negative correlation of small strength, but at the level of statistical significance where $r=-.148, p=.017$. We can interpret this relationship in the way that owners/entrepreneurs/managers, who attach great attention to personal goals, evaluate as less successful business of their own enterprise. In addition, the negative correlation of the 
Leković B., Marić S.: Measures of small business success/performance - importance...

similar strength, without statistical importance, also exists with the indicator of property growth $\mathrm{C} 2 \mathrm{~b} .03$, where $r=-.054$ and $\mathrm{p}=.410$, as well as with profit C2c.01, where $r=-.070$ and $p=.317$. It means that owners/entrepreneurs/managers who give priority to personal goals achieve less profit and growth of property of their own enterprise. This variable has a positive correlation at the level of small strength and without statistical importance with the growth indicator of the total income C2b.02, where $r=$ .068 and $p=.291$, as well as with the employment growth indicator where $r=-$ .011 and $p=.869$. We can interpret this that priority personal goals V/P/M contribute to bigger business volume through employment growth and total income.

Table 1. Correlation of subjective and objective criteria of success/performance

\begin{tabular}{|c|c|c|c|c|c|c|}
\hline & $\begin{array}{l}\text { C2d.02 } \\
\text { Business } \\
\text { of my own } \\
\text { enterprise } \\
\text { I consider }\end{array}$ & $\begin{array}{l}\text { C2b.01\% } \\
\text { growth } \\
\text { employme } \\
\text { nt in } \\
2012 ?\end{array}$ & $\begin{array}{c}\text { C2b.02 } \\
\% \\
\text { growth } \\
\text { of the } \\
\text { total } \\
\text { income } \\
\text { in } 2012 ?\end{array}$ & $\begin{array}{l}\text { C2b.03\% } \\
\text { growth of } \\
\text { the } \\
\text { property } \\
2012 ?\end{array}$ & $\begin{array}{l}\text { C2c.01 } \\
\text { Profit in } \\
2012 ?\end{array}$ & $\begin{array}{l}\text { C2c.02 } \\
\text { Profit per } \\
\text { employee } \\
\text { in } 2012 ?\end{array}$ \\
\hline \multirow{3}{*}{$\begin{array}{l}\text { C2d.01Business Pearson Correlation } \\
\text { success measured Sig. (2-tailed) } \\
\text { exclusively by } \\
\text { realized goals at the } \mathrm{N} \\
\text { private level...? }\end{array}$} &,$- 148^{*}$ & ,011 & ,068 &,- 054 &,- 070 & ,002 \\
\hline & ,017 & ,869 & 291 & ,410 & ,317 & ,973 \\
\hline & 260 & 244 & 243 & 233 & 209 & 212 \\
\hline \multirow{3}{*}{$\begin{array}{l}\text { C2d.02 Business of Pearson Correlation } \\
\text { my own enterprise I } \\
\text { consider ... }\end{array}$} & & $189^{* *}$ &, $271^{\text {** }}$ &, $261^{* *}$ &, $211^{\text {** }}$ & ,220** \\
\hline & & ,003 & ,000 & ,000 & ,002 & ,001 \\
\hline & & 244 & 243 & 233 & 209 & 212 \\
\hline
\end{tabular}

Source: Authors' calculation

In addition, we can see from the analysis of available correlation results that I consider variable C2d.02 Business of my own enterprise successful (at the scale from 1 to 5 , where 1 is incorrect, and 5 is correct). It has the positive correlation of small strength at the level of statistical significance with objective performance criteria and employment growth where $r=.189$ and $p=$ .003 , then with property growth where $r=.261$ and $p=.000$, with profit where $r=.211$ and $p=.002$, as well as with profit per employee where $r=.220$ and $p=.001$. This connectivity of subjective success evaluation of owners/entrepreneurs/managers and the objective performance indicators can be characterized as complementary, i.e. they are the subjective 
Leković B., Marić S.: Measures of small business success/performance - importance...

evaluation, as well as formally stated performance indicators in the positive correlation so that the objective results of small enterprises still need not be really stated.

In next table 2, we can see results of correlation analysis in objective category of success/performance indicators.

Table 2. Correlations between subjective indicators of success/performance

\begin{tabular}{|c|c|c|c|c|c|c|}
\hline & & $\begin{array}{l}\text { C2b.01\% } \\
\text { growth } \\
\text { employment } \\
\text { in 2012? }\end{array}$ & $\begin{array}{l}\text { C2b.02\% } \\
\text { growth of } \\
\text { the total } \\
\text { income in } \\
2012 ?\end{array}$ & $\begin{array}{l}\text { C2b.03\% } \\
\text { growth of } \\
\text { the property } \\
2012 ?\end{array}$ & $\begin{array}{l}\text { C2c.01 } \\
\text { Profit in } \\
2012 ?\end{array}$ & $\begin{array}{l}\text { C2c.02 } \\
\text { Profit per } \\
\text { employee in } \\
2012 ?\end{array}$ \\
\hline \multirow{3}{*}{$\begin{array}{l}\text { C2b.01 \% growth } \\
\text { employment in 2012? }\end{array}$} & $\begin{array}{l}\text { Pearson } \\
\text { Correlation }\end{array}$ & 1 &, $250^{* *}$ &, $322^{* *}$ & ,071 & 041 \\
\hline & Sig. (2-tailed) & &, 000 &, 000 & ,320 &, 568 \\
\hline & $\mathrm{N}$ & 244 & 230 & 219 & 196 & 201 \\
\hline \multirow{2}{*}{$\begin{array}{l}\text { C2b.02 \% growth of } \\
\text { the total income in } \\
\text { 2012? }\end{array}$} & $\begin{array}{l}\text { Pearson } \\
\text { Correlation }\end{array}$ &, $250^{* *}$ & 1 &, $302^{* *}$ &, $285^{* *}$ & ,265 \\
\hline & $\begin{array}{l}\text { Sig. (2-tailed) } \\
\mathrm{N}\end{array}$ & $\begin{array}{r}, 000 \\
230 \\
\end{array}$ & 243 & $\begin{array}{r}, 000 \\
228 \\
\end{array}$ & $\begin{array}{r}, 000 \\
205 \\
\end{array}$ & $\begin{array}{r}, 000 \\
207 \\
\end{array}$ \\
\hline \multirow{2}{*}{$\begin{array}{l}\mathrm{C} 2 \mathrm{~b} .03 \% \text { growth of } \\
\text { the property 2012? }\end{array}$} & $\begin{array}{l}\text { Pearson } \\
\text { Correlation }\end{array}$ &, $322^{\text {** }}$ &, $302^{* *}$ & 1 & ,112 & 061 \\
\hline & $\begin{array}{l}\text { Sig. (2-tailed) } \\
\mathrm{N}\end{array}$ & $\begin{array}{r}, 000 \\
219\end{array}$ & $\begin{array}{r}, 000 \\
228\end{array}$ & 233 & $\begin{array}{l}116 \\
198\end{array}$ & $\begin{array}{r}, 387 \\
200 \\
\end{array}$ \\
\hline \multirow{2}{*}{ C2c.01 Profit in 2012? } & $\begin{array}{l}\text { Pearson } \\
\text { Correlation }\end{array}$ & 071 &, $285^{* *}$ & 112 & 1 &, $801^{\text {** }}$ \\
\hline & Sig. (2-tailed) & $\begin{array}{r}320 \\
196\end{array}$ & $\begin{array}{r}, 000 \\
205\end{array}$ & $\begin{array}{l}116 \\
198\end{array}$ & 209 & ,000 \\
\hline \multirow{3}{*}{$\begin{array}{l}\text { C2C.02 Profit per } \\
\text { employee in 2012? }\end{array}$} & $\begin{array}{l}\text { Pearson } \\
\text { Correlation }\end{array}$ &, 041 &, $265^{* *}$ & ,061 &, $801^{* *}$ & 1 \\
\hline & Sig. (2-tailed) &, 568 &, 000 & ,387 & ,000 & \\
\hline & $\mathrm{N}$ & 201 & 207 & 200 & 204 & 212 \\
\hline
\end{tabular}

**. Correlation is significant at the 0.01 level (2-tailed).

Source: Authors' calculation

The results indicate existence of two group objective indicators, financial, like profit and profit per employee and non-financial, like \% growth of the employment and \% growth of the property. Based on results, indicator \% growth of the total income represents strong connection between two extremes of the same group of indicators. On one hand, there are more financial indicators, profit and profit per employee, and on the other hand, there are more non-financial, \% growth of the employment and \% growth of the property. We can see these connections in the results of correlation with all other indicators, as statistically significant (in all cases value of $p=.000$ ) 
with middle level of strength. We can say for these results that they are very logical because on one hand, indicator \% growth of the total income is connecting with profit and profit per employee only if there is no investment in the form of growth of the property and employment. On the other hand, when we have investment in form of the growth of property and employment, than we do not have growth of profit indicators.

These results provide for reliability and usability of objective indicators of performance/success, in the form of formal reports, which is very important for owner/entrepreneur/manager of small business and for building up formal system of management.

Although this part of the analysis did not represent and was not based on the determined suppositions within the planned research aims, data availability, as well as the significance of analysed variables in the selected way gave significant information relating to the relationships and connections between observed occurrences and it largely contributed to the overall research results.

\section{Conclusion}

As the basic motivators of individuals for assessing entrepreneurial success are still unknown or restricted and set imprecisely; or they are primarily personal, there is a justified aspiration to contribute to understanding of every way of measuring success of owners/entrepreneurs/managers within every next research. Taking into consideration their personal values, since entrepreneurial personality is largely incorporated into business project by the analysis of many previous, as well as current researches, we can notice numerous criteria used by entrepreneurs for success measuring. Available literature points to the fact that owners/entrepreneurs/managers also use other criteria, especially in the domain of personal ambitions in order to evaluate their own success where social influence and personal satisfaction prevail.

One of the delicate tasks within this paper was to define the set of success/performance criteria of small business, on which the reliability of carried out research and relevancy of obtained results depended. Selected success/performance criteria had the basic purpose to represent real business results of small businesses, taking into consideration all the present characteristics. In spite of the shortcomings, showed in financial performance indicators of small enterprises, they were combined with subjective criteria to increase the usefulness of collected data. Therefore, in the set of criteria and taking largely into consideration the results of previous research, as well as available conditions and possibilities, we can find the indicators of growth, 
Leković B., Marić S.: Measures of small business success/performance - importance...

survival, profitability and subjective success evaluations of owners/entrepreneurs/managers.

On the basis of applied statistical methodology and analysis of the results we accept both hypotheses $\mathrm{H} 1$ and $\mathrm{H} 2$ because:

- There is a high level of reliability and usability of subjective success measures (in the form of subjective satisfaction about realizing the goals of owners/entrepreneurs/managers) as the positive correlation with objective (financial and nonfinancial) indicators of performance.

- There is a high level of reliability and usability of objective success measures (in the form of formal reports) as the positive correlation between two subgroups objective (financial and nonfinancial) indicators of performance.

We should emphasize that financial performance measures of small business are not sufficient for real and objective expression of realized business results and the statement of business success. It is because of shortcomings previously mentioned, but as it is difficult to measure and compare subjective criteria, the former cited choice is rationally necessary, i.e. the combination of subjective and objective success measures is desirable. As success in the context of small businesses, besides of all the characteristics of the role of owners/entrepreneurs/managers relates twofold to the degree of realizing the set goals, analysis of success is really needed, while there is still the dilemma about the real statement of objective (financial) performance indicators.

\section{References}

Baron, R.A., Markman, G.D. (2000) Beyond social capital: the role of social competence in entrepreneurs success, Academy of Management Executive, vol. 14, No. 1, pp. 41-60

Brooksbank, R., Kirby, D., Tompson, G., Taylor, D. (2003) Marketing as a Determinant of Long Run Competitive Success in Medium Sized U.K. Manufacturing Firms, Small Business Economics, vol. 20, no. 3, pp. 259-272;

Brush, C.G., Vanderwerf, P.A. (1992) A Comparison of Methods and Sources for Obtaining Estimates of New Venture Performance, Journal of Business Venturing, vol. 7, pp. 157-170;

Gibson, B., Cassar, G. (2005), Longitudinal Analysis of Relationships between Planning and Performance in Small Firms, Small Business Economics, vol. 25, pp. 207-222;

Gorgievski, M., J., Ascalan, M., E. U. Stephan, (2011) Small Business Owners Success Criteria, a Values Approach to Personal Differences, Journal of Small Business Management, 49(2), 207-232

Hughes, F.J., Simpson, M., J. Padmore (2007) "Inherent Limitations in Using Financial Ratio Analysis to Assess Small and Medium Sized Company Performance", The Management School, University of Sheffield. 
Leković B., Marić S.: Measures of small business success/performance - importance...

Jarvis, R., Curran, J., Kitching, J., Lightfoot, G. (2000) The Use of Quantitative and Qualitative Criteria in the Measurement of Performance in Small Firms, Journal of Small Business and Enterprise Development, vol. 7, no.1, pp. 123-134;

Jenning, P.L, Beaver, G. (1997) The Performance and Competitive Advantage of Small Firms: A Management Perspective, International Small Business Journal, vol. 15, no. 2 pp 63-75;

Knight F. H., (1971) Risk, Uncertainty and Profit, Chicago: University of Chicago Press

Luk, S. T. K, (1996) "Success in Hong Kong: Factors Self-reported by Successful Small Business Owners", Journal of Small Business Management, 34(3), 6874 ;

Lumpkin, G. T., Dess, G. G. (1996) Clarifying the entrepreneurial orientation construct and linking it to performance. Academy of management Review,21(1), 135-172;

Man, T.W.Y, Lau, T., Chan, K. F. (2002) The Competitiveness of small and medium enterprises: a conceptualization with focus on entrepreneurial competencies, Journal of Business Venturing, Vol. 14, No. 2, 123-142;

Markman, G., Baron, R. (2003) Person-entrepreneurship fit: why some people are more successful as entrepreneurs than others, Human Resource Management Review, Vol. 13, No. 2, pp. 281-301;

Marshall, A. (1890). 1916, Principles of Economics: An Introductory Volume.

Murphy, G. B., Trailer, J. W., Hill, R. C. (1996) Measuring performance in entrepreneurship research, Journal of business research, 36(1), 15-23;

Pennings, J. M., K. Lee, A. van Witteloostuijn, (1998) Human Capital, Sociao Capital and Firm Dissolution, Academy of Management Journal 41(4), 425-440;

Perren, L. (2000) Factors in the growth of micro-enterprises (part 2): exploring the implications. Journal of small business and enterprise development, 7(1), 5868 ;

Perry, S.C. (2001), The Relationship Between Written Business Plans and the Failure of Small Businesses in the U.S., Journal of Small Business Management, vol. 39 , no. 3, pp. 201-208;

Reid, G.C., Smith, J.A. (2000) What makes a new business start-up successful?, Small Business Economics, Vol. 14, pp. 165-182;

Rue, L.W., Ibrahim, N.A. (1998), The Relationship Between Planning Sophistication and Performance in Small Business, Journal of Small Business Management, vol. 36, no. 4, pp. 24-32;

Sapienza, H. J., C.M. Grimm, (1997) "Founder Characteristics, Start-Up Process, and Strategy/Structure Variables as Predictors of Shortline Railroad Performance", Entrepreneurship: Theory \& Practice 22(1), 5-24;

Say, J. B. (1971) "A Treatise on Political Economy or the Production, Distribution and Consumption of Wealth, New York: A Kelley Publishers

Simpson, M., Padmore, J., Frecknall-Hughes, J. (2007) Measuring the Performance of Small and Medium Sized Enterprises, Institute for Small Business \& Entrepreneurship, Conference Proceedings, Glasgow;

Simpson, M., Tuck, N., Bellamy, S. (2004) Small Business success factors: the role of education and training, Education and Training, Vol. 46, No. 8-9, pp. 481-491;

Stenberg, R. (2004) Successful intelligence as a basis for entrepreneurship, Journal of Business Venturing, Vol. 19, No. 2, pp. 189-201;

Venkataraman, N., Ramanujam, V. (1986) Measurement of business performance in strategy research: a comparison of approaches. Academy of management review, 11(4), 801-814. 
Leković B., Marić S.: Measures of small business success/performance - importance...

Wang, C.K., Ang, B.L. (2004) Determinants of venture performance in Singapore, Journal of Small Business Management, Vol. 42, No. 4, pp. 347-363;

Wickham, P. (2004) Strategic entrepreneurship, Prentice Hall;

Wilson, K. (2004) Entrepreneurship education at European universities and business schools. Survey report, Hilversum, NL: EFER and EFMD 